ISSN 0258-7122

Bangladesh J. Agril. Res. 37(2): 335-348, June 2012

\title{
VEGETATIVE GROWTH, HARVESTING TIME, YIELD AND QUALITY OF MANGO (Mangifera indica L.) AS INFLUENCED BY SOIL DRENCH APPLICATION OF PACLOBUTRAZOL*
}

\author{
BABUl C. SARKER ${ }^{1}$ AND M. A. RAHIM ${ }^{2}$
}

\begin{abstract}
The experiment was conducted during the fruiting season of 2005-06 to investigate the effects of paclobutrazol in manipulating the harvesting time, increasing yield and quality in mango (Mangifera indica) cv. BARI Aam-3 (Amrapali) plants at the BAU Germplasm Centre, FTIP, Department of Horticulture, Bangladesh Agricultural University, Mymensingh. Paclobutrazol at 2500, 5000, 7500, $10000 \mathrm{ppm}$, and control (water application) and two times of application (15 October and 15 December) were included in the study as treatments. Soil drench application of paclobutrazol at $10000 \mathrm{ppm}$ and 7500 ppm on 15 October was more effective in suppressing vegetative growth i.e. terminal shoot length, number of leaves and leaf area compared to control. Both 7500 ppm and 10000 ppm paclobutrazol applied as soil drench on 15 October caused earlier panicle emergence by 19 days as well as harvesting by 15 days compared with control. Applying paclobutrazol at $7500 \mathrm{ppm}$ on 15 October produced the highest number of fruits as well as yield per plant and the heaviest fruit compared with the lowest yield in control. Paclobutrazol at $7500 \mathrm{ppm}$ applied on 15 October also resulted in higher edible portion, lower stone pulp ratio and peel pulp ratio, longer shelf life, higher TSS, increased vitamin C, lower titratable acidity, higher dry matter, reducing, non-reducing and total sugar contents as compared to control plants. The present results suggest that the application of paclobutrazol at 7500 ppm in October enhances yield and quality in mango.
\end{abstract}

Keywords: Yield and quality of mango, soil drench application of Paclobutrazol.

\section{Introduction}

Mango (Mangifera indica L.) because of its great utility, occupied a pre-eminent place amongst the fruit crops grown in Bangladesh. Presently, mango is produced about 242605 tons from an area of 51012 hectares with an average yield of 4.75 tons per hectare in Bangladesh (BBS, 2005), which is very low compared to other mango growing countries. The existing mango production falls appreciably short to fulfill the national demand. Irregular or erratic flowering, low fruit set as well as retention leading to low yield, fruits of poor quality and short availability period are the major problems in mango production. Extending availability

\footnotetext{
* a part of $\mathrm{Ph}$. D research work of the first author

${ }^{1}$ Senior Scientific Officer (Horticulture), Horticulture Research Centre, Regional Agricultural Research Station, Bangladesh Agricultural Research Institute (BARI), Jamalpur, ${ }^{2}$ Professor, Department of Horticulture, BAU, Mymensingh, Bangladesh.
} 
period in addition to increasing yield and quality adopting soil drenching of paclobutrazol in mango cv. BARI Aam -3 (Amrapali) would be very useful for the mango growers as its cultivation is being expanded rapidly throughout the country. Soil application of paclobutrazol induced precocious flowering in young trees and promoted early flowering in bearing trees (Kulkarni, 1988). Inflorescence becomes visible within 2.5 to 4 months after the application of paclobutrazol depending on cultivar (Junthasri et al., 2000). Improvement in fruit set and fruit retention in mango cv. Gulab Khas as well as the highest yields were recorded under soil application of paclobutrazol (Singh and Singh, 2006). Applying $10 \mathrm{ml}$ paclobutrazol had the greatest effect increasing all the parameters (ascorbic acid, total sugar, reducing sugar and TSS, except for acidity) in harvested fruits from 10 year-old trees of Alphonso mangoes at Coimbatore, India (Vijayalakshmi and Srinivasan, 2000). Compared with the control, trees treated with paclobutrazol had higher results for number of panicles produced, yield as well as quality of the fruit (Yeshitela et al., 2004). The research regarding regulation of flowering and harvesting time, increasing yield and quality of mango by using paclobutrazol is almost absent in Bangladesh. Considering the above facts, the present study was carried out to find out the effects of paclobutrazol on the manipulation of harvest time and improving yield as well as quality of mango cv. BARI Aam -3 (Amrapali).

\section{Materials and Method}

The experiment was carried out at the Germplasm Centre, Department of Horticulture, Bangladesh Agricultural University, Mymensingh which is located at $24^{0} 26^{\prime}$ latitude and $90^{\circ} 15^{\prime}$ longitude with an altitude of $8.3 \mathrm{~m}$ above the sea level during the fruiting season of 2005-06. Investigations related to bio-chemical analysis were carried out in the Department of Biochemistry of Bangladesh Agricultural University (BAU), Mymensingh. The 8 years old BARI Aam -3 (Amrapali) plants with a plant spacing of $5 \times 5 \mathrm{~m}$ were used in the study. The factorial experiment was laid out in a Randomized Complete Block Design with 3 replications. Paclobutrazol at 2500, 5000, 7500, 10000 ppm and control (water application) and two times of application (15 October and 15 December) were included in the study as treatments. The solutions of 2500, 5000, 7500 and 10000 ppm were prepared by dissolving 10, 20, 30 and $40 \mathrm{ml}$ of $25 \%$ paclobutrazol (Syngenta Chem. Co. Ltd., India) into 1litre of fresh water each respectively. Paclobutrazol treatments were soil drenched according to Burondkar \& Gunjate (1993), in which 10 small holes (10-15 cm depth) were prepared in the soil around the collar region of the plants just inside the fertilizer ring. The prepared solutions of paclobutrazol as per treatment uniformly drenched into the wholes and the soil was reworked after application of paclobutrazol. Only water was applied in the control plants. The data of the following parameters were recorded: length of terminal shoot, number of leaves per terminal shoot, leaf area, length of 
panicle, number of secondary branches per panicle, date of first panicle emergence, total number of panicles, fruit set per panicle, number of fruits retained per panicle at 10 day intervals starting from pea stage upto harvest, date of harvest, number of fruits per plant, fruit weight, yield, edible portion, stone pulp ratio, peel pulp ratio, shelf-life, TSS, titratable acidity, vitamin C, dry matter, reducing sugar, non reducing sugar and total sugar content. The length and number leaves of ten randomly selected terminal shoots at flowering stage were measured and the average was worked out. Leaf area was measured for all the 50 leaves taking 5 from each of ten above selected shoots by a leaf area meter and expressed as square centimeter. The length and number of secondary branches per panicle of 10 randomly tagged panicles covering the whole tree was recorded and the average was worked out. Ten panicles were randomly selected from each treatment. The initial number of fruits of each panicle and the fruits to be retained per panicle at 10 day intervals starting from pea stage up to harvest were recorded and the average was worked out. After harvest, ten randomly selected fruits were allowed to ripen at room temperature and fruit quality was determined using 10 fruits per tree. Total Soluble Solid (TSS) of 10 fully ripened fruits for each treatment was estimated by a hand refractometer and the average was worked out. The titratable acidity (Ranganna, 1979), vitamin C (Plummer, 1971), reducing sugar (Miller, 1972) and total sugar content (Jayaraman, 1981) in mango pulp were determined. The recorded data on different parameters of the experiment were tabulated and analyzed and the treatment means were separated by Least Significant Difference (LSD) test at $5 \%$ level of significance.

\section{Results and Discussion}

\section{Effect of paclobutrazol on leaf, shoot and panicle characters of mango}

Paclobutrazol treatments markedly influenced the terminal shoot length, number of leaves per terminal shoot, leaf area, panicle length, number of secondary branches per panicle and number of panicles per plant (Table 1). Regardless of the concentrations used, paclobutrazol caused a marked reduction in terminal shoot length, leaf number per terminal shoot and leaf area as compared with the control and the reduction of above traits was noted the maximum when paclobutrazol was applied in soil drenched at 10000 ppm which was closely followed by paclobutrazol at $7500 \mathrm{ppm}$. Plants received paclobutrazol at 7500 ppm produced the longest panicle, highest number of secondary branches per panicle and number of panicles per plant. There was significant variation due to time of application in respect of terminal shoot length and number of leaves as against no significant variation in leaf area, panicle length, number of secondary branches per panicle and number of panicles per plant (Table 2). Plants treated with paclobutrazol on 15 December demonstrated longer terminal shoot, higher number of leaves and panicles per plant as compared to those of 15 October 
application. The highest suppression of vegetative growth was manifested when paclobutrazol was treated at $10000 \mathrm{ppm}$ on 15 October (Table 3). According to Kurian and Iyer (1992) paclobutrazol can enhance the total phenolic content of terminal buds and alter the phloem to xylem ratio of the stem, which is important in restricting the vegetative growth and enhancing flowering by altering assimilate partitioning and patterns of nutrient supply for new growth. Suppressed vegetative growth of 'Tommy Atkins' mango trees due to soil drench application of paclobutrazol at 5.50 and $8.25 \mathrm{~g}$ a.i. per tree are reported (Yeshitela et al., 2004). Soil drench applications of Cultar (Paclobutrazol) to mango cv. Dashehari at Ludhiana prior to flower bud differentiation during the first week of October affected the vegetative growth and promoted flowering (Zora et al., 2000). According to Cardenas and Rojas (2003) paclobutrazol inhibited the vegetative growth and stimulated flower development. Length of panicle, number of secondary branches per panicle and number of panicles per plant were noticed to be higher when paclobutrazol was used at $7500 \mathrm{ppm}$ on 15 October (Table 3). The soil-applied paclobutrazol treatments at $7500 \mathrm{ppm}$ had an impact on reduction of vegetative growth, resulting in a higher intensity of flowering. Higher total non-structural carbohydrates (TNC) in the shoots of the paclobutrazol treated trees 2 weeks before flowering compared with the control have been reported by Yeshitela et al. (2004). He also stated that the increased number of panicles for paclobutrazol treated plants was due to lower expenditure of tree reserves to the vegetative growth parameters and consequently no assimilates limitations, compared with an excessive vegetative growth on the control trees. A higher accumulation of reserves in the current year shoots before flowering was also observed by Stassen and Janse Van Vuuren (1997). Either $7500 \mathrm{ppm}$ or $10000 \mathrm{ppm}$ paclobutrazol solution applied as soil drench on 15 October exhibited the earliest panicle emergence by 19 days, compared to control (Table 3). Flowering earliness in paclobutrazol treated plants was reported by Kulkarni (1988). He also ascribed that the flower-inductive factor might commence earlier in the season. It is also probable that the application of paclobutrazol caused an early reduction of endogenous gibberellins levels within the shoots as also observed by Anon. (1984), causing them to reach maturity earlier than those of untreated trees. This finding is similar to that of Tran et al. (2002), where paclobutrazol induced flowering 85 days after treatment application. The total activity of auxin-like substances increased the higher starch reserve, total carbohydrates and higher $\mathrm{C}$ : $\mathrm{N}$ ratio in the shoots favour flower bud initiation in mango (Jogdande and Choudhari, 2001). Regular, profuse and early bearing was also reported to be found due to paclobutrazol application in mango cv. Banganapalli grown at Andaman and Nicobar Islands, India (Singh and Ranganath, 2006). 
Table 1. Leaf, shoot and panicle characters of mango as influenced by paclobutrazol.

\begin{tabular}{l|c|c|c|c|c|c}
\hline $\begin{array}{l}\text { Paclobutrazol } \\
\text { concentration }\end{array}$ & $\begin{array}{c}\text { Length of } \\
\text { terminal } \\
\text { shoot } \\
(\mathrm{cm})\end{array}$ & $\begin{array}{c}\text { No. of } \\
\text { leaves/ } \\
\text { terminal } \\
\text { shoot }\end{array}$ & $\begin{array}{c}\text { Leaf } \\
\text { area } \\
\left(\mathrm{cm}^{2}\right)\end{array}$ & $\begin{array}{c}\text { Length of } \\
\text { panicle } \\
(\mathrm{cm})\end{array}$ & $\begin{array}{c}\text { No. of } \\
\text { secondary } \\
\text { branches/ } \\
\text { panicle }\end{array}$ & $\begin{array}{c}\text { No. of } \\
\text { panicles/ } \\
\text { plant }\end{array}$ \\
\hline $2500 \mathrm{ppm}$ & 14.66 & 9.66 & 56.49 & 23.03 & 24.30 & 61.67 \\
$5000 \mathrm{ppm}$ & 11.21 & 8.91 & 52.10 & 23.59 & 27.55 & 71.58 \\
$7500 \mathrm{ppm}$ & 9.87 & 8.25 & 48.76 & 24.03 & 30.33 & 115.67 \\
$10000 \mathrm{ppm}$ & 8.51 & 7.47 & 48.30 & 20.72 & 23.19 & 105.17 \\
Control (water & 21.12 & 13.17 & 59.87 & 18.95 & 21.92 & 55.33 \\
application) & & & & & & \\
\hline CV(\%) & 9.94 & 11.20 & 7.23 & 6.97 & 6.70 & 8.55 \\
LSD (0.05) & 1.58 & 1.29 & 4.65 & 1.87 & 2.07 & 8.50 \\
\hline
\end{tabular}

Table 2. Leaf, shoot and panicle characters of mango as influenced by time of paclobutrazol application.

\begin{tabular}{l|c|c|c|c|c|c}
\hline Time application & $\begin{array}{c}\text { Length of } \\
\text { terminal } \\
\text { shoot }(\mathrm{cm})\end{array}$ & $\begin{array}{c}\text { No. of } \\
\text { leaves/ } \\
\text { terminal } \\
\text { shoot }\end{array}$ & $\begin{array}{c}\text { Leaf area } \\
\left(\mathrm{cm}^{2}\right)\end{array}$ & $\begin{array}{c}\text { Length } \\
\text { of } \\
\text { panicle } \\
(\mathrm{cm})\end{array}$ & $\begin{array}{c}\text { No. of } \\
\text { secondary } \\
\text { branches/ } \\
\text { panicle }\end{array}$ & $\begin{array}{c}\text { No. of } \\
\text { panicles/ } \\
\text { plant }\end{array}$ \\
\hline 15 October & 11.38 & 7.78 & 51.83 & 22.23 & 25.80 & 87.10 \\
15 December & 14.77 & 11.21 & 54.38 & 21.90 & 25.12 & 76.67 \\
\hline CV(\%) & 9.94 & 11.20 & 7.23 & 6.97 & 6.70 & 8.55 \\
LSD (0.05) & 1.00 & 0.82 & - & - & - & 5.37 \\
\hline
\end{tabular}

Table. 3. Leaf, shoot and panicle characters of mango as influenced by the combined effect of paclobutrazol and its time of application.

\begin{tabular}{|c|c|c|c|c|c|c|c|c|}
\hline $\begin{array}{l}\text { Paclobutrazol } \\
\text { concentration }\end{array}$ & $\begin{array}{l}\text { Time of } \\
\text { application }\end{array}$ & \begin{tabular}{|l} 
Length \\
of \\
terminal \\
shoot \\
$(\mathrm{cm})$ \\
\end{tabular} & $\begin{array}{l}\text { No. of } \\
\text { leaves/ } \\
\text { terminal } \\
\text { shoot }\end{array}$ & $\begin{array}{c}\text { Leaf } \\
\text { area } \\
\left(\mathrm{cm}^{2}\right)\end{array}$ & $\begin{array}{c}\text { Length of } \\
\text { panicle } \\
(\mathrm{cm})\end{array}$ & $\begin{array}{c}\text { No. of } \\
\text { secondary } \\
\text { branches/ } \\
\text { panicle }\end{array}$ & $\begin{array}{c}\text { Date of } \\
\text { first } \\
\text { appearance } \\
\text { of panicle }\end{array}$ & $\begin{array}{c}\text { No. of } \\
\text { panicles/ } \\
\text { plant }\end{array}$ \\
\hline \multirow[t]{2}{*}{$2500 \mathrm{ppm}$} & & 11.87 & 60 & 53.30 & 3 & 26.11 & 24.01 .06 & 66.00 \\
\hline & $15 \mathrm{D}$ & 17.45 & 11.67 & 59.67 & & & & 57.33 \\
\hline \multirow[t]{2}{*}{$5000 \mathrm{ppm}$} & 150 & 9.60 & 6.61 & 51.03 & 23.62 & & 24 & 67.50 \\
\hline & $15 \mathrm{D}$ & 12.82 & 11.21 & 53.17 & & & 28. & 75.67 \\
\hline \multirow[t]{2}{*}{$7500 \mathrm{ppm}$} & $15 \mathrm{Oc}$ & 8.13 & 6.17 & 47.76 & 24.23 & 22 & 18. & 125.00 \\
\hline & 15 Dec & 11.62 & 10.33 & 49.77 & 23.83 & 29.44 & 27.0 & 106.33 \\
\hline \multirow[t]{2}{*}{$10000 \mathrm{ppm}$} & 15 October & 6.90 & 5.67 & 48.59 & 21.31 & 23.44 & 18.01.06 & 120.67 \\
\hline & $15 \mathrm{D}$ & 10.11 & 9.28 & 48.01 & & & & 89. 67 \\
\hline \multirow{2}{*}{$\begin{array}{l}\text { Control (water } \\
\text { application) }\end{array}$} & $15 \mathrm{O}$ & 20.40 & & 58.48 & & & & \\
\hline & $15 \mathrm{De}$ & 21.85 & 13.58 & 61.26 & 19.15 & 22.17 & 06.02.06 & 54.33 \\
\hline \multicolumn{2}{|l|}{ CV (\%) } & 9.94 & 11.20 & 7.23 & & & & 8.55 \\
\hline \multicolumn{2}{|l|}{ LSD (0.05) } & 2.23 & 1.82 & 6.58 & 2.64 & 2.92 & - & 12.01 \\
\hline
\end{tabular}


Table 4. Fruit set and number of fruits retained per panicle as influenced by the combined effect of paclobutrazol and its time of application.

\begin{tabular}{|c|c|c|c|c|c|c|c|c|c|c|c|}
\hline \multirow{2}{*}{$\begin{array}{l}\text { Paclobutrazol } \\
\text { concentration }\end{array}$} & \multirow[b]{2}{*}{$\begin{array}{c}\text { Time of } \\
\text { application }\end{array}$} & \multirow{2}{*}{$\begin{array}{c}\text { Fruit set } \\
\text { per } \\
\text { panicle }\end{array}$} & \multicolumn{9}{|c|}{ No. of fruits retained per panicle at } \\
\hline & & & $\begin{array}{c}22.03 . \\
06\end{array}$ & $\begin{array}{c}01.04 . \\
06\end{array}$ & $\begin{array}{c}11.04 . \\
06\end{array}$ & $\begin{array}{c}21.04 . \\
06\end{array}$ & $\begin{array}{c}01.05 . \\
06\end{array}$ & 11.05 .06 & $\begin{array}{c}21.05 .0 \\
6\end{array}$ & $\begin{array}{c}31.05 .0 \\
6\end{array}$ & $\begin{array}{l}\text { Har- } \\
\text { vest }\end{array}$ \\
\hline \multirow[t]{2}{*}{$2500 \mathrm{ppm}$} & 15 October & 13.32 & 3.32 & 2.53 & 1.59 & 1.35 & 1.35 & 1.27 & 1.20 & 1.13 & 1.13 \\
\hline & 15 December & 12.33 & 2.90 & 2.12 & 1.34 & 1.12 & 0.96 & 0.97 & 0.97 & 0.87 & 0.87 \\
\hline \multirow[t]{2}{*}{$5000 \mathrm{ppm}$} & 15 October & 21.83 & 5.67 & 3.67 & 2.33 & 1.45 & 1.45 & 1.45 & 1.35 & 1.35 & 1.35 \\
\hline & 15 December & 19.64 & 4.93 & 2.40 & 1.83 & 1.33 & 1.07 & 1.07 & 1.07 & 0.93 & 0.93 \\
\hline \multirow[t]{2}{*}{7500 ppm } & 15 October & 28.08 & 7.37 & 6.20 & 3.70 & 2.32 & 2.23 & 2.23 & 2.23 & 2.15 & 2.10 \\
\hline & 15 December & 24.21 & 6.22 & 4. 57 & 2.58 & 2.30 & 1.85 & 1.78 & 1.78 & 1.65 & 1.65 \\
\hline \multirow[t]{2}{*}{10000 ppm } & 15 October & 20.08 & 5.23 & 2.70 & 2.17 & 1.57 & 1.50 & 1.43 & 1.30 & 1.30 & 1.30 \\
\hline & 15 December & 15.89 & 4.10 & 2.02 & 1.57 & 1.55 & 1.17 & 1.10 & 1.10 & 1.10 & 1.10 \\
\hline \multirow{2}{*}{$\begin{array}{l}\text { Control (water } \\
\text { application) }\end{array}$} & 15 October & 8.49 & 2.70 & 2.03 & 1.22 & 1.08 & 0.83 & 0.77 & 0.67 & 0.67 & 0.67 \\
\hline & 15 December & 9.33 & 3.13 & 2.58 & 1.33 & 1.10 & 1.03 & 0.95 & 0.87 & 0.87 & 0.72 \\
\hline \multicolumn{2}{|l|}{ CV (\%) } & 9.89 & 8.42 & 4.13 & 5.01 & 4.78 & 7.72 & 6.19 & 7.01 & 7.15 & 7.83 \\
\hline \multicolumn{2}{|l|}{ LSD (0.05) } & 2.94 & 0.66 & 0.22 & 0.17 & 0.12 & 0.18 & 0.13 & 0.15 & 0.14 & 0.16 \\
\hline
\end{tabular}




\section{Combined effect of paclobutrazol and time of application on fruit set as well as fruit retention of mango}

The combined effect of paclobutrazol concentrations and their time of application in terms of fruit set as well as number of fruits retained per panicle varied significantly (Table 4). Plants soil drenched with paclobutrazol at $7500 \mathrm{ppm}$ on 15 October resulted in the highest fruit set as well as fruit retention per panicle up to harvest. The control plants got the least fruit set and fruit retention per panicle. Trees soil drenched with paclobutrazol, which had higher reserves enhanced fruit set compared to the lowest fruit set in the untreated tree with low reserves because of excessive vegetative growth (Yeshitela et al., 2004) corroborate the present findings.

Table 5. Number of fruits per plant and fruit characters of mango as influenced by the effect of paclobutrazol.

\begin{tabular}{l|c|c|c|c|c|c}
\hline \multicolumn{1}{c}{$\begin{array}{c}\text { Paclobutrazol } \\
\text { concentration }\end{array}$} & $\begin{array}{c}\text { No. of fruits } \\
\text { per plant }\end{array}$ & $\begin{array}{c}\text { Fruit wt } \\
\text { (g) }\end{array}$ & $\begin{array}{c}\text { Edible } \\
\text { portion } \\
(\%)\end{array}$ & $\begin{array}{c}\text { Stone } \\
\text { pulp ratio }\end{array}$ & $\begin{array}{c}\text { Peel } \\
\text { pulp } \\
\text { ratio }\end{array}$ & $\begin{array}{c}\text { Shelf life } \\
\text { (days) }\end{array}$ \\
\hline $2500 \mathrm{ppm}$ & 43.08 & 216.02 & 66.09 & 0.25 & 0.25 & 7.01 \\
$5000 \mathrm{ppm}$ & 52.17 & 243.62 & 66.69 & 0.24 & 0.24 & 7.06 \\
$7500 \mathrm{ppm}$ & 106.32 & 330.44 & 69.18 & 0.22 & 0.22 & 7.25 \\
$10000 \mathrm{ppm}$ & 73.00 & 254.65 & 67.58 & 0.24 & 0.23 & 6.99 \\
Control (water & 31.33 & 200.80 & 65.19 & 0.27 & 0.30 & 6.58 \\
application) & & & & & & \\
\hline CV (\%) & 6.46 & 4.86 & 2.42 & 5.41 & 5.46 & 4.80 \\
LSD (0.05) & 4.79 & 14.69 & 1.96 & 0.01 & 0.01 & 0.41 \\
\hline
\end{tabular}

Table 6. Number of fruits per plant and fruit characters of mango as influenced by the effect of time of paclobutrazol application.

\begin{tabular}{l|c|c|c|c|c|c}
\hline $\begin{array}{c}\text { Time of } \\
\text { application }\end{array}$ & $\begin{array}{c}\text { No. of } \\
\text { fruits/ plant }\end{array}$ & $\begin{array}{c}\text { Fruit wt } \\
\text { (g) }\end{array}$ & $\begin{array}{c}\text { Edible } \\
\text { portion } \\
\text { (\%) }\end{array}$ & $\begin{array}{c}\text { Stone } \\
\text { pulp ratio }\end{array}$ & $\begin{array}{c}\text { Peel pulp } \\
\text { ratio }\end{array}$ & $\begin{array}{c}\text { Shelf life } \\
\text { (days) }\end{array}$ \\
\hline 15 October & 70.77 & 250.63 & 67.54 & 0.24 & 0.24 & 7.15 \\
15 December & 51.59 & 247.59 & 66.35 & 0.25 & 0.25 & 6.81 \\
\hline CV (\%) & 6.46 & 4.86 & 2.42 & 5.41 & 5.46 & 4.80 \\
LSD (0.05) & 3.03 & - & - & - & - & 0.29 \\
\hline
\end{tabular}

Combined effect of paclobutrazol and time of application on harvest time, number of fruits, yield and fruit characters

The date of harvest ranged between 10 June 2006 and 25 June 2006 having the earliest harvest by 15 days in plants treated with paclobutrazol either at 7500 
ppm or at $10000 \mathrm{ppm}$ on 15 October and the dalayed harvest in control plants (Table 7). The earlier harvest due to paclobutrazol of the current study is in line with the result of Xie et al. (1999), where spraying of paclobutrazol in late August/early September in the southwestern part of Hainan province had promoted flowering and ripening date by 1-3 months. The advancement of harvesting by 40-45 days in case of paclobutrazol application in mango cv. Banganapalli grown at Andaman and Nicobar Islands, India (Singh and Ranganath, 2006) provides support to the result of the present investigation. Paclobutrazol irrespective of concentrations exhibited earlier harvest than that of the control. Number of fruits per plant, fruit weight, edible portion, stone pulp ratio, peel pulp ratio, shelf-life and yield due to the concentration of paclobutrazol and the combined effect were noticed to be significant while time of application had significant effect only on number of fruits, shelf life and yield. (Table 5-7). Irrespective of concentration, paclobutrazol increased the number of fruits per plant although the highest number of fresh fruits per plant was harvested from the plants soil drenching with paclobutrazol at $7500 \mathrm{ppm}$, whereas the control plants gave the lowest number of fruits. Applying paclobutrazol on 15 October noted higher number of fruits per plant. The result revealed that October application of paclobutrazol exhibited superior performance in terms of fruit number over December application. The highest number of fruits per plant was harvested from the plants combinedly treated with $7500 \mathrm{ppm}$ paclobutrazol on 15 October compared to the lowest value in control. Plants treated with paclobutrazol at $7500 \mathrm{ppm}$ also recorded the heaviest fruit, highest edible portion, lowest stone pulp and peel pulp ratio and highest shelf-life when compared with the control (water application). Plants received paclobutrazol on 15 October produced higher shelf-life. Paclobutrazol at 7500 ppm applied on 15 October attained the heaviest fruit, highest edible portion, lowest stone pulp and peel pulp ratio and maximum shelf-life. The highest yield (37.85 kg/plant) was noted in plants which received paclobutrazol at $7500 \mathrm{ppm}$ as against the very low yield (6.34 kg/plant) in control. Plants treated with paclobutrazol on 15 October resulted in higher yield as compared to 15 December. The plants soil drenching with paclobutrazol at $7500 \mathrm{ppm}$ on 15 October got the highest yield (48.64 kg/plant), whereas the lowest yield (5.90 $\mathrm{kg} / \mathrm{plant}$ ) was recorded in control plants. A significantly higher fruit set and fruit retention in the paclobutrazol treated plants had a favourable impact on culminating higher final fruit number and yield per plant. Paclobutrazol has been reported to exert influence on partitioning the photosynthates to the sites of flowering and fruit production consequent to the reduction of vegetative growth. In this context, Kurian et al. (2001) reported that paclobutrazol appeared to favourably alter the source sink relationship of mango to support fruit growth with a reduction in vegetative growth. Plants treated with paclobutrazol at $7.5 \mathrm{~g}$ a.i. per plant of mango cv. Langra in Sabour, Bihar, India produced the highest 
Table 7. Date of harvest, number of fruits and fruit characters of mango as influenced by the combined effect of paclobutrazol and its time of application.

\begin{tabular}{|c|c|c|c|c|c|c|c|c|}
\hline $\begin{array}{l}\text { Paclobutrazol } \\
\text { concentration }\end{array}$ & $\begin{array}{c}\text { Time of } \\
\text { application }\end{array}$ & $\begin{array}{l}\text { Date of } \\
\text { harvest }\end{array}$ & $\begin{array}{c}\text { No. of fruits/ } \\
\text { plant }\end{array}$ & $\begin{array}{l}\text { Fruit wt. } \\
\text { (g) }\end{array}$ & $\begin{array}{c}\text { Edible } \\
\text { portion (\%) }\end{array}$ & $\begin{array}{l}\text { Stone pulp } \\
\quad \text { ratio }\end{array}$ & $\begin{array}{l}\text { Peel pulp } \\
\quad \text { ratio }\end{array}$ & $\begin{array}{l}\text { Shelf life } \\
\text { (days) }\end{array}$ \\
\hline \multirow[t]{2}{*}{$2500 \mathrm{ppm}$} & 15 October & 19.06 .06 & 47.33 & 219.97 & 66.39 & 0.25 & 0.25 & 7.29 \\
\hline & 15 December & 19.06.06 & 38.83 & 212.08 & 65.78 & 0.26 & 0.26 & 6.74 \\
\hline \multirow[t]{2}{*}{$5000 \mathrm{ppm}$} & 15 October & 19.06 .06 & 55.67 & 244.18 & 67.18 & 0.24 & 0.24 & 7.32 \\
\hline & 15 December & 19.06.06 & 48.67 & 243.07 & 66.20 & 0.24 & 0.24 & 6.81 \\
\hline $7500 \mathrm{ppm}$ & 15 December & 15.06 .06 & 77.17 & 324.39 & 68.15 & 0.23 & 0.23 & 7.01 \\
\hline \multirow[t]{2}{*}{$10000 \mathrm{ppm}$} & 15 October & 10.06 .06 & 80.33 & 258.73 & 68.82 & 0.23 & 0.23 & 7.13 \\
\hline & 15 December & 15.06 .06 & 65.67 & 250.58 & 66.35 & 0.25 & 0.24 & 6.85 \\
\hline \multirow{2}{*}{$\begin{array}{l}\text { Control (water } \\
\text { application) }\end{array}$} & 15 October & 25.06 .06 & 35.07 & 193.78 & 65.12 & 0.27 & 0.30 & 6.51 \\
\hline & 15 December & 25.06 .06 & 27.60 & 207.83 & 65.26 & 0.27 & 0.30 & 6.66 \\
\hline
\end{tabular}


Table 8. Fruit quality attributes of mango as influenced by the combined effect of paclobutrazol concentration and its $\stackrel{\omega}{\ddagger}$ time of application.

\begin{tabular}{|c|c|c|c|c|c|c|c|c|}
\hline $\begin{array}{l}\text { Paclobutrazol } \\
\text { concentration }\end{array}$ & Time of application & $\begin{array}{l}\text { TSS } \\
(\%)\end{array}$ & $\begin{array}{l}\text { Titrata-ble } \\
\text { acidity (\%) }\end{array}$ & $\begin{array}{l}\text { Vitamin C } \\
\text { (mg/100 g } \\
\text { pulp) }\end{array}$ & $\begin{array}{l}\text { Dry matter } \\
\text { content } \\
(\%)\end{array}$ & $\begin{array}{l}\text { Reduc-ing } \\
\text { sugar } \\
(\%)\end{array}$ & $\begin{array}{l}\text { Non-redu- } \\
\text { cing sugar } \\
\quad(\%)\end{array}$ & $\begin{array}{c}\text { Total sugar } \\
\text { (\%) }\end{array}$ \\
\hline \multirow[t]{2}{*}{2500 ppm } & 15 October & 25.80 & 0.22 & 29.95 & 19.20 & 5.07 & 13.16 & 18.23 \\
\hline & 15 December & 25.00 & 0.23 & 29.38 & 19.22 & 5.00 & 12.98 & 17.98 \\
\hline 5000 ppm & 15 October & 26.15 & 0.22 & 30.98 & 20.02 & 5.17 & 13.41 & 18.58 \\
\hline \multirow[t]{2}{*}{7500 ppm } & 15 October & 28.55 & 0.20 & 34.67 & 22.90 & 5.52 & 14.30 & 19.82 \\
\hline & 15 December & 27.80 & 0.22 & 32.49 & 22.02 & 5.37 & 13.94 & 19.31 \\
\hline \multirow[t]{2}{*}{10000 ppm } & 15 October & 26.57 & 0.19 & 33.31 & 21.32 & 5.36 & 13.91 & 19.27 \\
\hline & 15 December & 24.94 & 0.20 & 31.51 & 20.53 & 5.26 & 13.64 & 18.90 \\
\hline LSD (0.05) & & 2.46 & 0.01 & 2.08 & 1.59 & 0.29 & 0.65 & 1.03 \\
\hline
\end{tabular}


number of fruits and yield (Karuna et al., 2007). Yeshitela et al. (2004) in cv. Tommy Atkins recorded yields ranging from 2-3 folds as compared to control mostly due to soil drenching of paclobutrazol. The results enumerated as above are in consonance with the results obtained in the current investigation. He claimed application of $8.25 \mathrm{~g}$ a.i. per tree paclobutrazol increased the weight of harvested fruit by $152.87 \%$ when compared with the control.

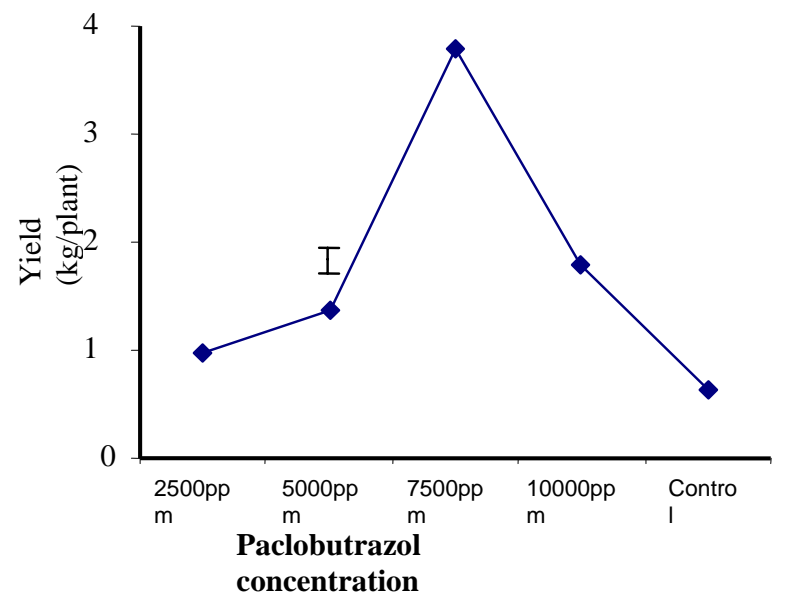

Fig. 1. Effect of paclobutrazol concentration on the yield per plant of mango. Vertical bar represents LSD at 5\% level.

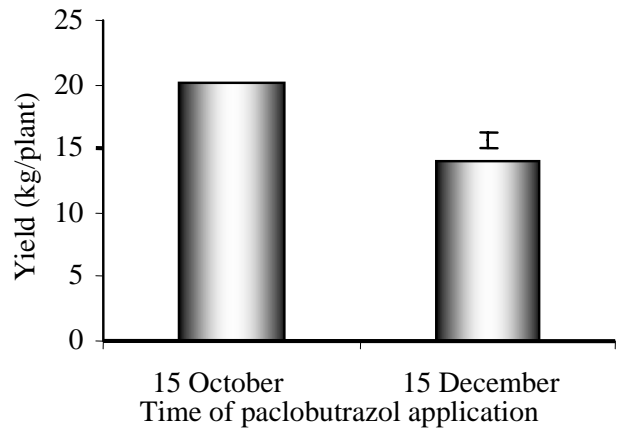

Fig. 2. Effect of time of paclobutrazol application on the yield per plant of mango.

Vertical bar represents LSD at 5\% level. 


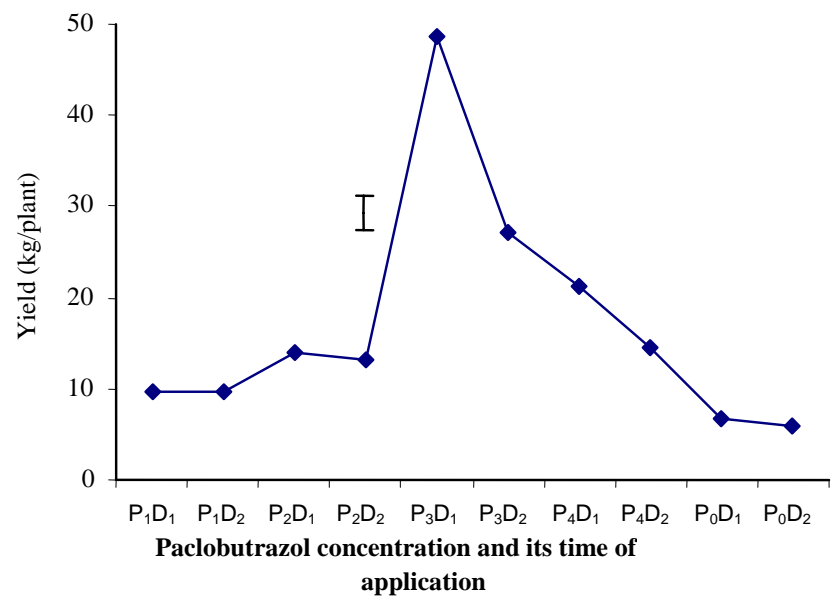

Fig. 3. Effect of paclobutrazol concentration and its time of application on the yield per plant of mango. Vertical bar represents ISD at 5\% level.

$$
\begin{aligned}
& \mathrm{P}_{1}: \text { Paclobutrazol at } 2500 \mathrm{ppm} \\
& \mathrm{P}_{2}: \text { Paclobutrazol at } 5000 \mathrm{ppm} \\
& \mathrm{P}_{3}: \text { Paclobutrazol at } 7500 \mathrm{ppm} \\
& \mathrm{P}_{4}: \text { Paclobutrazol at } 10000 \mathrm{ppm} \\
& \mathrm{P}_{0}: \text { Control (water application) }
\end{aligned}
$$

$$
\begin{aligned}
& \mathrm{D}_{1}: 15 \text { October } \\
& \mathrm{D}_{2}: 15 \text { December }
\end{aligned}
$$

Combined effect of paclobutrazol and time of application on qualitative characters of mango

The combined effect of paclobutrazol and its time of application manifested significant variations in respect of TSS, titratable acidity, vitamin C, dry matter content, reducing sugar, non-reducing sugar and total sugar (Table 8). Paclobutrazol at $7500 \mathrm{ppm}$ showed superior performances in respect of all above qualitative characters compared to those of control. Yeshitela et al. (2004) claimed that paclobutrazol improved fruit quality. Vijayalakshmi and Srinivasan (2000) indicated that paclobutrazol when applied to 10 year-old trees of Alphonso mangoes at Coimbatore, India, had the greatest effect enhancing all the quality parameters (ascorbic acid, total sugar, reducing sugar and TSS, except for acidity). Early application of paclobutrazol in mango cvs. Dashehari and Langra was found to increase the quality parameter viz., TSS, acidity, sugar, and ascorbic acid (Singh et al., 2000). Paclobutrazol at 5, 7.5 and 10g a.i. exhibited better performance in respect of physico-chemical characteristics (pulp percentage, stone percentage, peel percentage, total soluble solid, titratable acidity, ascorbic acid, total reducing and non-reducing sugar) at edible ripe stage in mango cv. Langra at Bihar, India compared to the control (Karuna et al., 
2005). Singh and Singh (2006) stated that soil treatment either at 5 or $10 \mathrm{~g}$ a.i. per tree with paclobutrazol improved the fruit quality.

\section{Conclusion}

Soil drench application of paclobutrazol at 7500 ppm or 10000 ppm on 15 October caused earlier panicle emergence by 19 days and harvesting by 15 days in mango cv. BARI Aam -3 (Amrapali) compared with control. Paclobutrazol at $7500 \mathrm{ppm}$ on 15 October gave the highest yield, heaviest fruit and improved the fruit quality.

\section{References}

Anonymous. 1984. Paclobutrazol, plant growth regulator for fruit. London, Fern Hurst, I.C.I. (Plant Protection Division). 35 p.

BBS. 2005. Yearbook of Agricultural Statistics of Bangladesh 2004. Bangladesh Bureau of Statistics, Statistics Division, Planning Division, Ministry of Planning. Government of the People's Republic of Bangladesh. p. 90.

Burondkar, M. M. and Gunjate, R. T. 1993. Control of vegetative growth and induction of regular and early cropping in 'Alphonso' mango with Paclobutrazol. Acta Hort. 34: 206-215.

Cardenas, K and E. Rojas. 2003. Effect of paclobutrazol and nitrates of potassium and calcium on the development of the mango 'Tommy Atkins'. Efecto del paclobutrazol y los nitratos de potasio y calcio sobre el desarrollo del mango. 'Tommy Atkins'. Bioagro. 15(2): 83-90.

Jayaraman, J. 1981. Laboratoy Mannual in Biochemistry. Wiley Eastern Ltd., New Delhi, India. p. 62.

Jogdande, N. D. and K. G. Choudhari. 2001. Seasonal changes in auxin content and its role in flowering of mango (Mangifera indica L.). Orissa J. of Horticulture 29(2): $10-12$.

Junthasri, R., P. Nartvaranant, S. Subhadrabandhu and P. Tongumpai. 2000. Flower induction for producing off-season mango in Thailand. J. Appl. Hort. 2(1): 65-70.

Karuna, K., A. Mankar and J. Singh. 2005. Effect of urea and growth substances on yield and physico-chemical characteristics of mango. Horticultural Journal 18(3): 131-133.

Karuna, K., A. Mankar and J. Singh. 2007. Effect of urea and growth substances on yield and quality of mango cv. Langra. Orissa J. Hort. 35(1): 67-70.

Kulkarni,V. J. 1988. Chemical control of tree and promotion of flowering and fruiting in mango (Mangifera indica L.) using paclobutrazol. J. Hort Sci. 63: 557-566.

Kurian, R. M. and C. P. A. Iyer. 1992. Stem anatomical characteristics in relation to tree vigour in mango (Mangifera indica L.). Scientia Hort. 50: 245-253. 
Kurian, R. M., Y. T. N. Reddy, R. K. Sonkar and V. V. P.Reddy. 2001. Effect of paclobutrazol on source- sink relationship in mango (Mangifera indica L.). J. Appl. Hort. 3(2): 88-90.

Miller, G. L. 1972. Use of Dinitro Salicylic Acid Reagent for determination of reducing sugar. Anal. Chem. 31: 426-428.

Plummer, D. T. 1971. An Introduction to Practical Biochemistry. Tata McGraw Hill Pub. Com: Ltd. Bombay, New Delhi. p. 229.

Rangana, S. 1979. Mannual of Analysis of fruit and Vegetable Products. Tata McGrawHill Pub. Co. Ltd., New Delhi. p. 634.

Singh, D. B and H. R. Ranganath. 2006. Induction of regular and early fruiting in mango by paclobutrazol under tropical humid climate. Indian J. Hort. 63(3): 248-250.

Singh, S. and A. K. Singh. 2006. Regulation of shoot growth and flowering in mango cv. Gulab Khas by paclobutrazol. Annals Agric. Res. 27(1): 4-8.

Singh, D. K., S. Ram and S. Ram. 2000. Effect of paclobutrazol application on fruit quality of mango. Indian Agriculturist 42(2): 121-126.

Stassen, P. J. C. and B. P. H. Janse Van Vuuren. 1997. Storage, redistribution and utilization of starch in young bearing 'Sensation' Mango trees. Acta Hort. 455: 151-166.

Tran, V. H., T. Radanachaless, K. Ishihata, T. Shioya and T. Radhanachaless. 2002. Flower induction with chemicals in 'Cat Hoa Loc' mango trees grown in the Mekong Delta in Viet Nam. Japanese J. Trop. Agric. 46(2): 59-65.

Vijayalakshmi, D. and P. S. Srinivasan. 2000. Improving the quality attributes of 'off' year Alphonso mango through chemicals and growth regulators. Orissa J. Hort. 28(1): 31-33.

Williams, M. W. 1984. Use of bioregulators to control vegetative growth of fruit trees and improve fruiting efficacy. Acta Hort. 146: 97-104.

Xie, G. G., B. Q. Xie, G. G. Xie and B. Q. Xie. 1999. Key cultural techniques for high production and quality from mango trees. South China Fruits 28(3): 25-26.

Yeshitela, T., P. J. Robbertse and P. J. C. Stassen. 2004. Paclobutrazol suppressed vegetative growth and improved yield as well as fruit quality of 'Tommy Atkins' mango (Mangifera indica) in Ethiopia. New Zealand J. Crop and Hort. Sci. 32(3): 281-293.

Zora, S., Z. Singh, W. Muller, F. Polesny, C. Verheyden and A. D. Webster. 2000. Effect of Paclobutrazol on tree vigour, flowering, fruit set and yield in mango. Acta Hort. 525: 459- 462. 